\title{
The ugly in fine arts. The sensory nature of terror in the tales of the Brothers Grimm
}

\author{
Theoretical assumptions
}

The sensory nature of terror announced in the subtitle was inspired by philosophical aesthetic reflection and refers directly to the fascination with ugliness found in tales. Even though the consideration of aesthetics as a science covering the meeting area of man and aesthetic qualities ${ }^{1}$ is highly controversial ${ }^{2}$, it seems to utilise study methods enabling one to notice and understand the excessive use of cruelty. The anachronism, a lack of precision, and notional vagueness it has been accused of (often resulting from indefinability) are not equivalent to slender value of cognitive qualities. Though the study subject is a unique text (not a philosophical reflection on art in general), the methodological assumptions of aesthetics are not incorrect.

Even though aesthetic consideration is rooted in antiquity (digressions regarding art and beauty can be found in Plato's works), it was the turn of the $19^{\text {th }}$ c. that brought about (alongside the emergence of the theoretical discipline) the multi-faceted focus on the subject of aesthetics.

\footnotetext{
* M.A., e-mail: szwajkowskaanita@interia.pl; Chair of Journalism and Social Communication, Faculty of Philology, University of Lodz.

${ }^{1}$ Cf. R. Ingarden, „Studia z estetyki”, Vol. 1, PWN, Warsaw 1957, pp. 224-267.

2 "The controversial nature of aesthetics is revealed not only when deciding upon basic issues, such as: the nature of beauty and an aesthetic experience, the manner of existence of aesthetic qualities of works of art and artistic output, definability of art, its function in people's lives, justifiability and verifiability of the valuation of art, etc. Any possible doubts and controversy apply to the status of aesthetics itself as a study discipline, and the need and sense in practising it, as well as its place among other philosophical disciplines, and its mutual relations with art criticism and other art sciences. Interestingly enough, the doubts and reservations towards aesthetics are made not only by the representatives of other art sciences and other philosophical disciplines. They are also recurrently raised by aestheticians themselves; every now and again they talk about the crisis or the twilight of their discipline" (B. Dziemidok, "Główne kontrowersje estetyki współczesnej", Wydawnictwo Naukowe PWN, Warsaw 2009, p. 7).
} 
Today, aesthetics is usually understood as a philosophical discipline which is a philosophy of aesthetic phenomena (objects, qualities, experiences, and values), or a philosophy of art (creativity, works of art, and their reception), or a philosophy of the broadly considered art criticism (meta-criticism), or, finally, it is a discipline which conducts, from the philosophical point of view, the merging of those three inter-connected areas ${ }^{3}$.

The placement of aesthetics at the borderline between philosophy, art and experience opens up research opportunities not only for philosophers, but also for crowds of outsiders ${ }^{4}$ : artists, historians, critics, as well as psychologists, sociologists, pedagogues, communication researchers, technicians, engineers, etc. "That is where [they] can talk to each other, and each of them introduces their own sensitivity and competences, though all remember that they are to perform philosophy, which must remain in contact with art"5. Thus aesthetics, losing its purely philosophical character, opens up to more and more bold and controversial projects.

The multi-dimensional and multi-faceted nature of the systems of reference of aesthetics requires the researcher each time to define the scope within which she/ he will operate. Thus: quoting the German philosopher A. Baumgarten ${ }^{6}$, I posit that aesthetics is a science on light and vague cognition fulfilled through one's senses, parallel to logic, a science on light and clear cognition fulfilled through one's intellect'. In my study, the etymological meaning of the word aesthetics shall remain fundamental, and in that instance I concur with the opinion of the creator of that term that beauty is the main subject of perception for all forms of sensory cognition. Aesthetics does not only focus on studying and describing beauty in art and nature, but it is also interested in that which is ugly.

"Experiences associated with art do not have to be elevating," argued A. Berleant, "they can be repelling. [...] If we accept that the quality of being aesthetic begins and ends there where one comes into contact with a sensory experience, then we may, theoretically at least, discuss in terms of its aesthetics any object and any experience that can be felt ${ }^{8}$.

\footnotetext{
${ }^{3}$ B. Dziemidok, op. cit., p. 16.

${ }^{4}$ L. Pareyson, „Estetyka. Teoria Formatywności”, transl. by K. Kasia, Towarzystwo Autorów i Wydawców Prac Naukowych Universitas, Cracow 2009, pp. 25-28.

${ }^{5}$ Ibid., p. 27.

${ }^{6}$ Alexander Gottlieb Baumgarten proposed and introduced in philosophy the term aesthetics in a publication devoted to the theory of cognition entitled "Aesthetica" (1750). He derived the term from Greek words aisthanomai (feel through senses) and aisthesis (sensory feeling) (as cited in: B. Dziemidok, op. cit., pp. 16-17).

${ }^{7}$ B. Dziemidok, op. cit., p. 16.

${ }^{8}$ A. Berleant, "Wrażliwość i zmysły. Estetyczna przemiana świata człowieka", transl. by S. Stankiewicz, Towarzystwo Autorów i Wydawców Prac Naukowych Universitas, Cracow 2011, p. 40.
} 
Regardless of whether they are positive or negative, sensory experiences are always marked by a series of external elements. Apart from biological influences, they are shaped by social, cultural, and historical factors9. Thus understood, sensory experiences possess an absolute value which, apart from the artist, the work, and the receiver of art, constitutes one of the elements of an aesthetic situation. The formal definition of aesthetic qualities proposed by Maria Gołaszewska emphasised "the special property of some items which belong to the human world" 10 , while informally the quality can be stated as the raison d'etre of a work of art. Quoting R. Ingarden the researcher indicated the objective nature of the aesthetic quality assigning it a sensory quality. He often stressed in his discussions "that the value remains in the area of that which is perceptible through the senses, which can be recognised through specific direct experience" ${ }^{\prime 1}$. Therefore, the meaning of an aesthetic experience lies in the search for (finding) of that quality.

The axiological nature of the study subject, i.e. value, not only influences its evaluation, but also significantly influences its academic status. Among the many methodological approaches, there has been an attempt to define in what sense value exists ${ }^{12}$. There are two standpoints: on the one hand, some claim that the value is fully dependant on the subject, others, on the other hand, claim that the value is inherent within an object. That is a typical example of the dichotomy between subjectivity and objectivity of perception ${ }^{13}$. If there exist no definitive arguments, one can posit that while coming into contact with nature or art, the aesthetic experience developing in human beings sees value in the aesthetic subject in some instances, while in the aesthetic object in others. That influences the nature of an aesthetic experience: irrational, expressive, habitual, understanding, or professional. An irrational aesthetic experience is emotional in nature, it is short-lived, and it is accompanied by somatic symptoms (increased heart rate, shivers, tears, etc.) When the receiver identifies a work of art and experiences it in an unconstrained way, according to her/her own personal inclinations, that is a case of an expressive aesthetic experience. In the case of an habitual aesthetic experience, the aesthetic value of an object is not as much given to the receiver as presumed by her/him (a work that is not generally appreciated deserves recognition). In the case of the merging of the emotions evoked by coming into contact with a work (aesthetic sensitivity) and the knowledge about that work (resulting from a study of culture or from upbringing and acquiring specific habits), the receiver develops

\footnotetext{
${ }^{9}$ Ibid., pp. $45-63$.

${ }^{10}$ M. Gołaszewska, “Zarys estetyki. Problematyka, metody, teorie”, PWN, Warsaw 1984, p. 350.

${ }^{11}$ M. Gołaszewska, “Zarys...”, op. cit., p. 350.

${ }^{12}$ Cf. M. Gołaszewska, "Fascynacja złem. Eseje z teorii wartości”, Wydawnictwo Naukowe PWN, Warsaw-Cracow 1994.

${ }^{13}$ Cf. M. Gołaszewska, “Zarys...”, op. cit., pp. 372-385.
} 
an understanding aesthetic experience. Art critics, theoreticians, and art historians and aestheticians participate in a professional aesthetic experience ${ }^{14}$.

For the aesthetic discipline, the notion of value constitutes a fundamental category, within which there is a division into specific aesthetic categories, including beauty and ugliness - concepts which seemingly imply each other. However, the acceptance of the existence of various aesthetic values does not enable one in any way to categorise or grade them. Every time after axiological consideration it is necessary to apply extensive methodological caution as even an attempt "at defining the scope of aesthetic values between the extremes of positivity and negativity will lead to a huge simplification of their standard-based scope and complexity"15. That becomes absolutely clear when one realises that ugliness, just like beauty, evokes aesthetic pleasure, and that beauty can be discovered in various forms of ugliness: "uneasy, disharmonious, full of stress and conflict, not soothing rather arousing, shattering the bond between humans and the world, full of contradictory elements" $" 16$.

Due to the fact that every researcher can assume her/his own convention when defining open terms (which clearly, within the aesthetic approach, include ugliness), and specify a class of phenomena which she/he intends to define, I shall consider ugliness as a series of aesthetically pejorative values which evoke negative sensations among receivers ${ }^{17}$. Those include all blatant diversions from that which in a sensory-focussed system evokes positive or at least neutral feelings, e.g.: deformity, repugnance, repulsion, aversion, terror, disgust, sadness, fear, anguish, humiliation, anger, impotence, heartache, criminality, ghastliness, hellishness, and anxiety. I believe that only such an understanding of ugliness acquires complete autonomy in the art world as an aesthetic value by becoming the subject of aesthetic experience. By being closer to real life than to refined beauty, it emphasises expressiveness assigning "items and phenomena a quality of rapacity, eeriness, and dread"18.

\section{The aesthetics of cruelty}

Many of the 210 tales by the Brothers Grimm were created in mediaeval Europe as stories intended for adult readers. Jacob and Wilhelm collected them at the request of their friend, who was planning to publish an anthology of German

${ }^{14}$ Ibid., pp. 299-307.

${ }^{15}$ A. Berleant, op. cit., p. 172 [English version tanslated from Polish].

${ }^{16}$ M. Gołaszewska, "Zarys...", op. cit., p. 352.

${ }^{17}$ An exceptionally detailed analysis of the ugliness of the spirit, character and art can be found in J. Rosenkranz's book entitled "Estetica del brutto".

${ }^{18}$ M. Gołaszewska, “Zarys...”, op. cit., p. 361. 
folk literature. When he abandoned his plans, the brothers edited the texts, and having branded them with a title "Children's and Household Tales" they published them in 1812 in Germany. Initial editions, filled with notes and devoid of any illustrations, were not intended for children. It was only the 1825 edition which included tempered versions of 50 tales with illustrations by Ludwig Grimm, that was prepared for younger readers. Wilhelm, encouraged by the edition's great commercial success, began tempering the stories and editing the tales adjusting them for children, yet not eliminating terror elements all together.

The ugliness present in the tales, having an overwhelming effect on one's mood, helps present the world full of mystery, monstrosities, and cruelty, a world exaggerated in its barbarity. Or at least that is how it is perceived by contemporary readers who sometimes seem to forget that the narration in the Brothers Grimm's tales reflected the actual brutality of mediaeval life, when abandoning children or burning women suspected of witchcraft at the stake was nothing out of the ordinary. By drawing from folk art ${ }^{19}$, the Brothers Grimm expressed the apotheosis of "vitality, wishful thinking, rationalisation of fears and terrors" ${ }^{20}$ in a rather perverse manner. While presenting folk beliefs and visions of the surrounding world, they did not shun away from an almost obsessive "admiration" for ugliness. They were surely aware of the fact that by placing the characters in a dark impassable forest, they automatically created an atmosphere of menace and tension. An atmosphere actively embraced by the readers, who wholeheartedly reject the real world as, according to M. Gołaszewska, "on the one hand, we are fascinated by that which is beautiful and, on the other, we are drawn to that which is ugly, ghastly, and repugnant" ${ }^{21}$. People expect soothing from beauty. Ugliness should stimulate, shatter the inner order, and break patterns and stereotypes.

According to psychoanalysists, the manifestations of ugliness present throughout the tales stimulate the human subconscious. Bruno Bettelheim assigned a therapeutic value to tales: indirect suffering, i.e. experienced only in one's imagination, helps children relieve internal tension (by embodying deep desires), achieve a balance between their own perceptions and the internal world, and to accept their own real corporeality ${ }^{22}$. Additionally, when confronted with the menace and dread embodied by witches, ruthless step-mothers, blood-thirsty wolves, children realise that they can control their fear, whereas

19 "Grimm's Fairy Tales" are deeply rooted in folklore, the definitive features of which, according to J. Bartmiński, are spokenness, collectivity, and aestheticism (cf. J. Bartmiński, "Folklor język - poetyka", Zakład Narodowy im. Ossolińskich, Wrocław-Warsaw-Krakow 1990, p. 8).

${ }^{20}$ U. Chęcińska, "Baśń była na początku”, in: "Barwy świata baśni”, U. Chęcińska (ed.), Wydawnictwo Naukowe Uniwersytetu Szczecińskiego, Szczecin 2003, p. 8.

${ }^{21}$ M. Gołaszewska, "Zarys...", op. cit., p. 361.

${ }^{22}$ Cf. B. Bettelheim, "Cudowne i pożyteczne. O znaczeniach i wartościach baśni”, transl. by D. Danek, Państwowy Instytut Wydawniczy, Warsaw 1985, pp. 117-128. 
adults "in a mature manner understand what had remained in the child form (as a child's fear) in their unconscious" ${ }^{23}$. "The tales allow us to "express our utopian longings', says Jack Zipes of the University of Minnesota, whose 1987 translation of the complete fairy tales captured the rustic vigour of the original text. They show a striving for happiness that none of us knows but that we sense is possible. We can identify with the heroes of the tales and become in our mind the masters and mistresses of our own destinies" ${ }^{24}$.

\section{The study material and the aim of the study}

I selected the study material from three Polish editions of the tales:

1) P. Pullman, „Baśnie braci Grimm dla dorosłych i młodzieży”, Poznań 2014;

2) Bracia Grimm, „Wszystkie baśnie i legendy”, Warsaw 2012;

3) „Ptak - Straszydło i inne baśnie braci Grimm”, Warsaw 1990.

The selection was intentional. My goal was to choose texts which reflected the course of the narration as closely to the originals (heard by the Brothers Grimm at the beginning of the $19^{\text {th }} \mathrm{c}$.) as possible because my initial assumption was that the marks of intellectual terror should not be sought in literary variants with extensive staging of the classical Walt Disney productions style, which differs considerably from the original folklore-derived tales. Tales in the majority of which the characters were devoid of any personal features, which lacked detailed descriptions, the narration was flat and unsophisticated, and the story focussed only on the events. The deficiency of means of expression did in no way depreciate the work because "a successful work of art is one which is the most effective (has the strongest effect on the receiver) while using the least amount of means of expression (the least words, tones, and sounds for achieving the intended artistic effect)"25. A lack of stylistic abuses and the economic use of descriptions emphasises the realism of the content at the same time stimulating the readers' imagination.

The fabulous dark creations of dejection discussed herein, which pester the imagination of the readers possess every time a sensory pedigree. In the indicated examples that meant sensory perception, which apart from superficial qualities covers "each and every dimension of our experience, and our sensory consciousness" 26 ; participates in the creation of artistic values; and presents diverse aesthetic values, ugliness included.

${ }^{23}$ Ibid., p. 91.

24 T. O’Neill, “Strażnicy krainy Baśni”, National Geographic 1999, Issue 3, p. 28 (Englis version: http://www.nationalgeographic.com/grimm/article.html [accessed on: 14.06.2017]).

${ }^{25}$ M. Gołaszewska, “Zarys...”, op. cit., p. 375.

${ }^{26}$ A. Berleant, op. cit., p. 134 [English version translated from Polish]. 
Traditionally, we identify two distance senses, i.e. vision and hearing, and three senses requiring closeness: touch, taste, and smell. However, that list is not complete ${ }^{27}$. When seeking sensory manifestations of ugliness, I only used the five classical sensory experiences: sight, hearing, smell, taste, and touch ${ }^{28}$. I abandoned any detailed study for the benefit of clarity and coherence of the discussion, at the same time remembering that intertwining individual aesthetic experiences evoke in readers feelings not only based on simple sensory sensations. Cultural influences transcending sensory perception each time are also of certain significance. And even though an organisation of the analysis into a description of specific senses resembles, in essence, a non-heart-based study, it offers the tools enabling methodical reflection on the imagined aesthetic values.

The biggest value of tales is that they reach the zone of the unconscious directly by utilising, apart from symbolic meanings, an extensive influence using the imagined sensory perception. Thus stimulated aesthetic engagement is the reason why receivers lose sight of the line between that which is material and that which is immaterial. It would be difficult to image a stronger effect words can have on the human psyche. Words cease to be used for communicating fictional content, and begin to create in the subconscious a reality which evokes a whole spectrum of emotional reactions. "Indeed, we recognize," said Arnold Berleant, "that the absorption in aesthetic appreciation may at times be so complete that the

${ }^{27}$ Contemporary aesthetics has broadened the list of senses considerably. The proposal of Guy Marchie (1978) has remained the most extensive in terms of both quantity and quality. In "Siedem tajemnic życia. Badania naukowe i filozoficzne" (The Seven Mysteries of Life: An Exploration of Science and Philosophy), he identified five groups which consisted of 32 senses in total. The first group were the senses of radiation: vision, heliotropism, sensitivity to radio waves and temperature; the second - the senses of feeling: hearing, the sensation of pressure, touch, the sense of balance, the sense of space; the third consisted the senses of chemistry: smell, taste, hunger and craving, and the sensation of moisture; the fourth group consisted of the senses of mind: the sensation of pain, fear, the need for amusement, the sense of time, the cognitive ability, intuition, the sense of beauty; the final fifth group consisted of the senses of spirit: the sensation of love, guilt, and forgiveness (as cited in: M. Gołaszewska, Estetyka wspótczesności, Wydawnictwo Uniwersytetu Jagiellońskiego, Cracow 2001, p. 187). Clearly all of the listed senses participate in an aesthetic experience forming inseparable channels for human perception "which enable synthetic experience" (A. Berleant, op. cit., p. 100). Therefore, any further detailing and developing of the list of senses does not seem, from the point of view of the hereby discussion, necessary.

${ }^{28}$ The highly-sensory Brahman philosophy also includes only five senses, which (to emphasise human unity with the world) were assigned five types of substances. In the $5^{\text {th }}$ c. A.D., Kanada (the founder of one of the six systems of classical Hindu philosophy - Vaisheshika) argued that the material world is constituted of five elements and five senses. Thus: "Earth is the carrier of scent and it forms the appropriate sense of smell. Water possesses the property of taste, and it forms the sense of taste. Fire is the carrier of colour, and it forms the sense of vision. Air is responsible for property and the sense of touch, while space (ether) is responsible for the property of sound and the sense of hearing" (cf. "Estetyka czterech żywiołów. Ziemia, woda, ogień, powietrze", K. Wilkoszewska (ed.), Towarzystwo Autorów i Wydawców Prac Naukowych Universitas, Cracow 2002, pp. 14-15). 
viewer, reader, or listener abandons entirely the consciousness of a separate self and enters totally into the aesthetic world" 29 .

This analysis of individual cases constitutes only a case-based introductory study of the issue of senses in literary texts. Due to the fact that "in the world of art there are no actual or physical results, only spiritual ones located within the realm of experiences and feelings" 30 , I seek in the texts of tales such fragments of the stories which would suggest specific sensations caused in the real world through the application of physical stimuli. I find it as much obvious as provoking further reflection that an imagined image, sound, scent, taste or touch can evoke real emotions in their receivers - complex, temporarily limited psychological states encompassing physiological, consciousness-based, and behavioural changes.

I believe that the physical manifestations of fear experienced while reading (mainly by the youngest readers), such as sweating, trembling, blushing or paling, rapid breath, a feeling of a lump in one's throat, and the sensations of a chill or hotness, are the result of sharing the sensations felt by the fabulous characters. One of the stimuli which cause somatic symptoms is an imagined (not experienced) sensory sensation.

I do not focus on the tale as an independent existential creation, which carries a multitude of interpretative references and meanings, only the possibilities offered by the analysis of a work, which consists of a transfer of a literary description to the imagination of the sensory experience occurring (hypothetically) in the receiver's imagination.

\section{Aesthetic sensitivity associated with the sense of vision}

In the Grimm Brothers' fairy tales, one can find manifestations of unimaginable cruelty and sadism forming together the stories being told or even obscuring them. It comes as no surprise, then, that in the $19^{\text {th }} \mathrm{c}$. parents, teachers and the clergy tenaciously condemned the savagery and obscenity of "Children's and Household Tales". The outrage caused by them resulted from the erroneous belief that the monstrous visions were real ${ }^{31}$, not mere metaphors for internal psycho-

\footnotetext{
${ }^{29}$ A. Berleant, op. cit., p. 101. (English version: https://ndpr.nd.edu/news/sensibility-and-sensethe-aesthetic-transformation-of-the-human-world/ [accessed on: 14.06.2017]).

${ }^{30}$ S. Szuman, "Wybór pism estetycznych", Towarzystwo Autorów i Wydawców Prac Naukowych Universitas, Cracow 2008, p. 382.

31 There has survived a speech by an American preacher of 1885, in which he warned against the detrimental influence of the "Grimms' Fairy Tales": "The folktales mirror all too loyally the entire medieval worldview and culture with all its stark prejudice, its crudeness and barbarities." (T. O’Neill, op. cit., p. 8).
} 
logical processes translated into visual images ${ }^{32}$. And even though their menace becomes evident at various levels of perception, the visual creations surely constitute the most intensively represented group of "acting through fear".

Even though the tales are filled with descriptions of impassable, thick and dark forests, and evil witches end their lives in bread ovens, the Brothers reach the height of the macabre in the suggestive descriptions of chopped-up human remains. From the many tales based on the motif of obvious evil, I chose three where the crimes terrify even more as they do not offer a simple justification. The suffering applies to innocent beings and not evil characters, which through their doings deserved their punishments, e.g. the evil step-mother in "Snow White", who gets forced to dance in red hot iron shoes, or the insidious and deceitful maid in "The Goose Girl", who dies in a barrel with internal spikes.

A true psychological deviation, which M. Gołaszewska defines as a "moral sickness" where a person knows she/he is committing an evil deed yet continues as she/he finds in that some sick pleasure ${ }^{33}$, could be found in "The Sea-Hare". It is the story of a proud queen, who saw in marriage only complete submission to a man. In order to remain free till the end of her life and thus retain a firm grasp on her rule, she announced that her husband can only be a person who can hide from her sharp eyesight. And since there existed special conveniences (the girl possesses 12 magic windows through which she could see anything on and under ground), it was no difficult feat to thwart any marital plans of young men. Until that point, it is a contemporarily accepted story of a liberated feminist. It is only the vision of the terrible fate that threatens anyone who willingly attempts to hide from the princess's view that evokes a strong reaction in the readers. If found, the men are beheaded and their heads are impaled. When the story begins, there are ninety-seven spikes in front of the castle, each of which carries a head. The atrocious murders alone evoke opposition and aversion, but it is the vision of the profaned bodies of the wretched souls that is both visually and morally repulsive.

The Brothers Grimm mentioned in just one sentence the punishment prepared for the suitors who do not succeed in avoiding the girl's all-seeing eyes. The lack of a plastic vision of the impaled heads of the poor men stimulates the readers' imagination. Goggled eyes, tongues sticking out, and hair sticky with blood are just an innocent image of the scene served by one's mind.

A blood-curdling story between a dream and reality can also be found in a more obscure version of the tale of Godfather Death - "The Godfather". The protagonist - an excellent physician - is steadfast in fighting for his patients' lives,

${ }^{32}$ B. Bettelheim, "O sztuce opowiadania baśni”, in: "Antropologia słowa. Zagadnienia i wybór tekstów”, G. Godlewski (ed.), Wydawnictwa Uniwersytetu Warszawskiego, Warsaw 2003, pp. 219-224.

${ }^{33}$ M. Gołaszewska, "Fascynacja złem...”, op. cit., p. 71. 
at the same time breaking the rules set by his godfather: Death ${ }^{34}$. Struggling with internal problems, he travels to his benefactor's home. While climbing the stairs, he passes fragments of talking human remains (chopped off fingers and heads) to, on the final fifth floor, find the bedroom of his godfather, who turns out to be a hellish monster. The issue of evil adopts its final symbol: the folk vision of a horned devil. "The devil [...] embodies the utmost evil, and his figure yields ugliness in the entanglement of the shapes of various animals, and unnatural tones and the cruelty of crimes" ${ }^{\prime 3}$. Crimes, which in that case assume the shape of actual dismembered human bodies.

The realisation of early and cruel death, amplified by the macabre image of a blood-stained bowl filled with chopped-up human remains, is yet another sinister vision, this time presented in "Fitcher's Bird". Terror enclosed in a torture chamber, based on the bestiality of the murderer of young women, enables one to see and feel that which is dark, evil and primitive in the human psyche, and that which, due to cultural considerations, should be completely ousted and yet endures ${ }^{36}$. The story has a benign beginning: a man wants to marry a submissive woman whom he could trust. He showers each of the women he selects with gold and fulfils all their wishes under one condition: they cannot enter a forbidden room. To amplify the temptation, he leaves the palace giving them the key to the closed chamber. Their curiosity shall be punished by death: Since thou hast gone into the room against my will, thou shalt go back into it against thine own. Thy life is ended.

In that tale as well the Brothers Grimm left much freedom to their readers, as the image drawn by them is not the only carrier of terror - it only indicates the possible directions of its visualisations. In other words, the receivers are offered an extensive selection of the visions of evil, and their imaginations are usually quite efficient in offering an answer to the pestering questions: how big is the room? what do the walls look like? where is the tub with the remains? which human parts stick out? how many of them are there? how decomposed are they? Cognition, in that case understood as one's vision of the forbidden room, reflects each time the special character of the person engaged in it. Moreover, the images created in one's imagination constitute only one form of cognition. Consecutive re-readings of the text constitute consecutive attempts at a gradual deepening of previous visualisations, since:

Neither unity nor the definitive nature of interpretation are meaningful. When we consider interpretability, we are faced with an unlimited number of possibilities and

${ }^{34}$ The tale features a godfather, not a godmother, as Death in German (the original language of the tale) is masculine (der Tod).

${ }^{35}$ M. Gołaszewska, "Fascynacja złem...,", op. cit., p. 138.

${ }^{36}$ Cf. C.G. Jung, "Archetypy i nieświadomość zbiorowa", transl. by R. Reszke, Wydawnictwo KR, Warsaw 2016. 
an endless process. Interpretation is endless in its number and process, and it is characterised by both qualitative and quantitative infinity ${ }^{37}$.

Under the cloak of blood, violence and helplessness, one finds in the quoted tales the marks of folk justice, where there is no place for forgiveness, where that which counts is the motivation not the deed. The studied manifestations of evil were deeply rooted in the customs of the Middle Ages where the fight for earthly possessions (the king's daughter's hand), disloyalty towards a man (girls opening the forbidden chamber), or, eventually, the attempted discussion on the meaning and the necessity of death are strictly prohibited.

\section{Aesthetic sensitivity associated with the sense of touch}

"Beauty, and human sensory experiences and existence in the world offer a special unity which can be felt, e.g. through touch, which provides rich feelings of pleasure or pain ${ }^{38}$, at the same time offering a sense of reality of the world" ${ }^{39}$, wrote M. Gołaszewska in the foreword to "Estetyka pięciu zmysłów". When attempting to "touch" the problem of touch, one quickly notices that it is not possible to communicate through it highly specialised emotions which are easily communicated through facial expressions or prosody. And yet touch is one of the most basic and natural forms of communication: sensitivity to touch is the first, assuming its formal function, sensory process in a person's development, and the final mode of conveying emotions for dying people. The aesthetic sensitivity associated with that sense, apart from visual creation, constitutes an invaluable method of exerting influence on the readers of tales, including the influence evoking negative emotional responses. The sensory experience (i.e. internal perception not preceded by external stimulation) of acute physical pain caused by pressure, cold or heat evokes deep emotional responses.

The readers of the Brothers' Grimm fairy tales, by associating with the oppressor or the victim, come into contact with evil as if participating in the act of cruelty. By "experiencing" death, they also "experience" the related physical suffering. However, in pre-Christian beliefs (on which the tales are based), the coming

${ }^{37}$ L. Pareyson, op. cit., p. 207.

${ }^{38}$ B. Scott argued that: "The skin is the largest of all the senses. Some physiologists consider touch as the only sense. Hearing starts with sound waves touching the inner ear; taste - with the corporeal touching of taste buds; and vision - with the soft stroke of the cornea. Therefore, other senses constitute derivatives of touch as the manifestations of the stimulation of the skin, muscles and blood vessels" (D.G. Leathers, "Komunikacja niewerbalna", transl. by M. Trzcińska, Wydawnictwo Naukowe PWN, Warsaw 2009, p. 140 [English version translated from Polish]).

${ }^{39}$ M. Gołaszewska, "Estetyka pięciu zmysłów”, Wydawnictwo Naukowe PWN, Warsaw-Cracow 1997, p. 8. 
into contact with the merciless physiological event of death did not constitute the end of pain. That is perfectly depicted in The Shroud, where the excessive sadness of the mother mourning her small, dead son results in the child's distress in afterlife. The boy appears to his mother in the white shroud in which he was put in the coffin and asks her to stop crying because he cannot fall asleep as the wet tear-soaked fabric sticks to his body. The sense of menace is evoked in readers by the vision of the intense cold associated with having wet clothes and is amplified by the setting in a graveyard pit.

The mother overflowing with tears is, according to folk traditions, behaving egoistically: the dead deserve rest while the living must do what they must to ensure that for them. The coming into contact with death evokes terror manifested as acute anxiety caused by the sense of loss, uncertainty or even the chaos of the surrounding world. The child's return from the dead restores the mother's shattered order and induces her to undertake the huge effort to stop grieving. Aware of the inappropriateness of her behaviour, she stops crying while the child: slept in its little bed beneath the earth.

When the dead rise from their graves, people are entitled to be afraid, to defend themselves. What should one do when they only reach out with their hands from their graves thus asking for forgiveness? Folk morality is absolute in that respect as well. Those who had not been forgiven while alive, do not deserve forgiveness once they are dead. Even a small child in "The Wilful Child" cannot hope for compassion. The parental (or rather motherly) curse is eternal: as its punishment, the naughty child becomes ill and dies, and when it reaches out with its hand in a begging gesture, the mother smacks it with a twig. The vision of the pain is itself terrible; what proves terrifying is that it is inflicted by the child's own mother. But the real shock is created by the circumstances.

In the discussed tales, the artists performed a kind of interpretation of evil, giving it a corporeal form. Through imagined tactile sensations they formed a new unique persuasive quality of aesthetic experience. By fluctuating between poetry and common sense, they did not strive to explain, clarify, or justify anything, simply indicating the fairness of the present order of things. The sensory awareness of pain enables the readers to symbolically fight evil, it offers a sense of certainty and community with the world in all its glory.

\section{Aesthetic sensitivity associated with the sense of hearing}

The human "ear" is accustomed to a specific range of sounds. Too powerful and sudden sounds evoke dejection, fright or quivering; they seem ugly and terrifying. So too do sounds which are harmonious and melodious yet come from un- 
natural sources. Just as in the case of the magic mouthpiece in the crime-style tale entitled "The Singing Bone". A shepherd herding his sheep over a bridge notices a white piece of bone on the bank of the stream and decides to carve a mouthpiece out of it for a horn. To his astonishment, when he blows into the horn, it resonates in a human voice. The readers are terrified both by the provenance of the sound and the story of the crime which it sings: one brother treacherously killed the other to rob him of his prey and thus marry a princess. Thus a skeleton abandoned on the side of the road demands justice and proper burial.

The vision of the melodious sound of the singing human bone evokes fright in readers, yet the experience of silence is even more menacing. Culturally speaking, silence is associated with a void or complete non-existence; in mythical consideration, it shatters the cognitive and emotional order. The fabulous perception of reality "offers" a voice to the dead and animals, it personifies gods, demons and death, it anthropomorphs inanimate nature, and all that according to the principle that the world must resonate. That is also why the biggest and the hardest challenge a human can face is a total prohibition to talk. In the Brothers' Grimm tales it is always women who become silent. Some of the more symptomatic stories are those where princesses unintentionally cause their brothers to be turned into birds ("The Six Swans" - into swans, "The Twelve Brothers" - into ravens) and in order to release them, they must perform the impossible: desist from any communication with their surroundings. Not only are they not allowed to speak, but even to use so-called body language. The prohibition to use any gestures or even smile during their long-term (six years in the former and seven years in the latter case) trial leads them to the stake. Wrongly accused by the jealous mothers of their husbands, they remain loyal to their brothers who at the last moment come to their rescue putting out the flames with their wings. Such a turn of events is not surprising, though. In a time when common sense was obscured by magical thinking, women were often suspected of magic and secret dealings with the devil. In the Middle Ages (i.e. when the stories formed in the spoken tradition), the vision of a Sabbat (a diabolic meeting during which witches not only cast spells, but also engaged in real orgies having intercourse with Satan in the form of a goat) was extremely popular and real. In fact, such legends did not form out of nowhere. "The so-called witches were old «wise women» who claimed to know about medicinal herbs and philtres. Others were poor charlatans who fed on the gullibility of the people, others again were genuinely convinced that they had had relations with the Devil. Clinical cases, obviously. Overall, however, witches represented a form of popular subculture" ${ }^{\prime 4}$.

Both silence as refraining from talking, and silence as a lack of any sounds perceivable by the human ear, possess a strong presence in fairy tales. Their inclusion

40 "Historia brzydoty", U. Eco (ed.), transl. by A. Gołębiowska and others, Dom Wydawniczy Rebis, Poznan 2009, p. 203 [English version: U. Eco, "On Ugliness", Harvill Seker, London 2007]. 
is indicated, yet authors do not waste time describing the emotions associated with them. It is the readers who discover the world of mute terror by imagining the requirement to remain completely silent, the inability to communicate using one's voice with those closest to them or by the unreal listening to silence. One can become accustomed to a scream full of pain or demonic noise. However, not to be able to hear or express objection - that is the cruellest of all tortures.

\section{Aesthetic sensitivity associated with the sense of taste}

Issues associated with taste are not particularly emphasised in the tales, however, if they appear, the impression they make is exceptionally strong. Throughout "Children's and Household Tales", the notion of cannibalism, which could compete with the best theatres of terror, appears several times. Even though the roots of anthropophagy in literature reach all the way to antiquity (Cronus devoured his own children; Tantalus cooked Pelops's son and served him to the gods to question their infallibility; Arteus fed his brother Thyestes the meat of his own son), encountering it in a folk story causes some distaste. Even more so since the detailed descriptions of the process of preparing the meal and the minute account of eating it do not always show the clearly metaphoric nature of the story.

The symbolic dimension of cannibalism can be found in, e.g. "The Juniper Tree", one of the most beautiful fairy tales by the Brothers Grimm, which combined the life-giving power of nature and cultural conditions. Its prelude is the wait for a child together with a description of the changing seasons, particularly in a juniper tree. The story proper starts when a woman dies in childbirth and is buried under the tree. Several years later, her son is brutally murdered and cooked by his emotionless stepmother. Having been eaten by the unsuspecting father and buried (the bones) under the tree, he transforms into a beautiful bird. In that form, he kills the vile stepmother, and becomes human again stepping out of the juniper tree.

The story, even though it possesses a happy ending, cannot be considered as a light story, or, even less so, "tasteful". The father who eagerly eats the stew made from the body of his little son appears repulsive to the readers, even though he compliments many times the excellent taste of the dish. The imagined taste of the delicious stew does not stimulate one's appetite, and the readers do not become hungry as is usually the case when one hears about delicious food.

While the story in "The Juniper Tree" has a happy ending and the eating of the boy by his father is only symbolic, "The Murderer's Bride" is a proper bloody story devoid of any supernatural elements. It shocks both through its form and content. During her wedding reception, a woman tells the story of robbers abducting, murdering, and eating young women. She ends each thought with: My 
love, I had but such a dream. At the climax, she presents the feasters a chopped off woman's finger with a beautiful ring thus proving that it was no dream and the person responsible for the crimes is her newly-wedded husband.

The story of cannibalism of corrupt men has had many variants, and is often used in contemporary literary texts and films. Its popularity can be explained with the human fascination with negative values, which because art, through its fictional nature, ensures some distance, "which mitigates or even removes altogether the ethical odium of evil, that moment of outrage, and moral disgust" take the form of tamed evil. Within the system of ethical values and the corresponding values of the types of aesthetic experiences ${ }^{42}$, even the most disgraceful deeds acquire a tint of innocence if they serve catharsis.

\section{Aesthetic sensitivity associated with the sense of smell}

Old women, witches, forest monsters, and devils are ugly but do they stink? One cannot deduce that from fairy tales. While taste sensations are not among those often emphasised, the issue of smell in fairy tales is virtually non-existent. The fabulous world "has no scent". That is surprising since smell "has a significant influence on the status of the autonomic nervous system and on emotions" as "almost every smell sensation carries an emotional component - it is either pleasant or annoying ${ }^{943}$. Even if one assumes that the indicated act of sensing does not occur in the case of imagined scent, there still remains the key question about the lack of even the metaphorical use of "fragrance".

The only text (out of 120 fairy tales in total) that raises the issue of aesthetic values derived from recreated scent is the story entitled "The Fisherman and His Wife". The tale presents in a particularly beautiful way the increasing dread of the situation being described. With the growing obsession of the poor fisherman's wife, the influence of sensory experience increases. Once-clear river water becomes dirtier, smellier, and foamed with each new wish spoken by him. In the climax, a terrible storm arrives in a very impressive manner, and the depths emit a terrible stench. The raging storm is aligned with the peak of the woman's guilt and madness serving the function of God's commentary to her caprices.

The perfectly formed tale "The Fisherman..." was written by a painter Philip Otton Runge and reached the Brothers Grimm as a manuscript. They themselves, while editing the oral texts, seem to have used the sense of smell only for identifying

\footnotetext{
${ }^{41}$ M. Gołaszewska, "Fascynacja złem...", op. cit., p. 87.

${ }^{42}$ M. Gołaszewska, "Estetyka pięciu zmysłów”, op. cit., p. 11.

${ }^{43}$ Ibid., p. 19.
} 
two orders: of nature and of culture. Witches moving between the world of man and animals revealed primal sensitivity to scents, including the scent of the human body. The evil witch in "Hansel and Gretel" senses the children's presence by only following their scent, thus the character acquires the features of a predator.

Vivid human imagination enables a recreation to be just as potent as a direct experience. However, in the case of the sense of smell, eidetic memory proves lacking. Even though the imagined form of an image, sound, taste and touch can, for most humans, evoke negatively marked emotions pestering their imaginations, it is much more difficult to produce dislike and aversion in the case of a scent; though it is possible.

\section{Conclusion}

"The relationship between aesthetics and art seems simple and straightforward: art creates artistic values, while aesthetics considers what their essence is" ${ }^{\prime 44}$. Aesthetic commentary on fairy tales enables one to come into contact with those values and (as a result) discover the existential meaning hidden in them. That is because of their inherent duality of reality: "actual reality and presented reality; the reality in which one acts and the reality which one views; the reality which is always the current challenge and the reality of memories, dreams, expectations, and spells"45, far too clearly presents the real world and everything it includes. Fairy tales constitute the markers of cultural heritage; they present in the form of a symbol both the light and the dark side of human existence, thus by holding the conscious and non-conscious powers they encompass the entirety of human psychic perfection.

The savagery presented in fairy tales is not purposeless - it sets off imagination and stimulates its development. They help younger readers overcome their fear of growing up. A child which faces the need to symbolically fight evil discovers that life brings not only happiness and pleasure, but also pain, loneliness, and trouble. It learns that both good and evil are everywhere in the world, and the mental experience of the joy in triumph and the bitter taste of defeat helps it understand and endure the pain of adolescence, the pain of maturation. Adults receive an opportunity to revisit the simplest, almost basic matters, which have become blurred through the years, and have been scattered as a result of the bitter experiences of their everyday lives.

${ }^{44}$ M. Sobeski, "Wybór pism estetycznych”, Towarzystwo Autorów i Wydawców Prac Naukowych Universitas, Cracow 2010, p. 202.

${ }^{45}$ M. Gołaszewska, "Kultura estetyczna", Wydawnictwa Szkolne i Pedagogiczne, Warsaw 1979, p. 87. 
By utilising symbolic imagery, fairy tales communicate folk wisdom: how to live! Yet how they do it is not straightforward. By operating on various levels (discussed in extenso by researchers in various fields: literary and folklore scientists, theoreticians expanding on Freud's, Jung's and Marx's thoughts and ideas, structuralists, postmodernists, and many, many more), they influence various aspects of human emotional life. Their strength and universal nature result from the fact that as they express rich internal content, they do not explain anything, only indicate what is right.

The Brothers' Grimm fairy tales identify the goal and the meaning of life thus giving people a sense of security in the world. And if one assumes that people learn and become accustomed to at least a portion of the real world through their senses, that would mean they use the imagined sensory vision of it. Therefore, by conducting a kind of interpretation of evil (condemning it by associating it with ugliness), my study was focussed on sensory vision or expectation (not experiences). Based on the assumption that an active participation in art requires each time a person to undertake the difficult task of interpreting it, an action the climax of which is the discovery of the true meaning of a work, I proposed to seek in the texts those passages which evoke sensory visions. Since "a work is imperfect and full of shortcomings" ${ }^{\prime 4}$, the readers" task is to identify and complete that which is "fortunately incomplete" ${ }^{47}$, including that which is sensory.

\section{Bibliography}

Bartmiński J., "Folklor - język - poetyka", Zakład Narodowy im. Ossolińskich, Wrocław-Warsaw-Krakow 1990.

Berleant A., "Wrażliwość i zmysły. Estetyczna przemiana świata człowieka”, transl. by S. Stankiewicz, Towarzystwo Autorów i Wydawców Prac Naukowych Universitas, Cracow 2011.

Bettelheim B., “Cudowne i pożyteczne. O znaczeniach i wartościach baśni”, transl. by D. Danek, Państwowy Instytut Wydawniczy, Warsaw 1985.

Bettelheim B., "O sztuce opowiadania baśni”, in: "Antropologia słowa. Zagadnienia i wybór tekstów”, G. Godlewski (ed.), Wydawnictwa Uniwersytetu Warszawskiego, Warsaw 2003, pp. 219-224.

Chęcińska U., "Baśń była na początku”, in: "Barwy świata baśni”, U. Chęcińska (ed.), Wydawnictwo Naukowe Uniwersytetu Szczecińskiego, Szczecin 2003, pp. 7-14.

Dziemidok B., "Główne kontrowersje estetyki współczesnej”, Wydawnictwo Naukowe PWN, Warsaw 2009.

“Estetyka czterech żywiołów. Ziemia, woda, ogień, powietrze”, K. Wilkoszewska (ed.), Towarzystwo Autorów i Wydawców Prac Naukowych Universitas, Cracow 2002.

Gołaszewska M., Estetyka współczesności, Wydawnictwo Uniwersytetu Jagiellońskiego, Cracow 2001.

\footnotetext{
${ }^{46}$ L. Pareyson, op. cit., p. 257.

${ }^{47}$ Ibid.
} 
Gołaszewska M., "Estetyka pięciu zmysłów”, Wydawnictwo Naukowe PWN, Warsaw-Cracow 1997.

Gołaszewska M., "Fascynacja złem. Eseje z teorii wartości”, Wydawnictwo Naukowe PWN, Warsaw-Cracow 1994.

Gołaszewska M., "Kultura estetyczna”, Wydawnictwa Szkolne i Pedagogiczne, Warsaw 1979.

Gołaszewska M., "Zarys estetyki. Problematyka, metody, teorie”, Wydawnictwo Naukowe PWN, Warsaw 1984.

"Historia brzydoty", U. Eco (ed.), transl. by A. Gołębiowska and others, Dom Wydawniczy Rebis, Poznan 2009 [English version: U. Eco, “On Ugliness”, Harvill Seker, London 2007].

Ingarden R., „Studia z estetyki”, Vol. 1, Wydawnictwo Naukowe PWN, Warsaw 1957.

Jung C.G., "Archetypy i nieświadomość zbiorowa", transl. by R. Reszke, Wydawnictwo KR, Warsaw 2016.

Leathers D.G., "Komunikacja niewerbalna", transl. by M. Trzcińska, Wydawnictwo Naukowe PWN, Warsaw 2009.

O’Neill T., "Strażnicy krainy Baśni”, National Geographic 1999, Issue 3, p. 28 (Englis version: http://www.nationalgeographic.com/grimm/article.html [accessed on: 14.06.2017]).

Pareyson L., „Estetyka. Teoria Formatywności”, transl. by K. Kasia, Towarzystwo Autorów i Wydawców Prac Naukowych Universitas, Cracow 2009.

Sobeski M., "Wybór pism estetycznych", Towarzystwo Autorów i Wydawców Prac Naukowych Universitas, Cracow 2010.

Szuman S., "Wybór pism estetycznych", Towarzystwo Autorów i Wydawców Prac Naukowych Universitas, Cracow 2008.

Anita Szwajkowska

\section{The ugly in fine arts. The sensory nature of terror in the tales of the Brothers Grimm}

\section{(Summary)}

The author, inspired by philosophical aesthetic reflection, presents one of the aesthetic qualities: ugliness. Based on the assumption that "Grimms' Fairy Tales" directly reach the realm of the unconscious, utilising towards that end not only symbolic meaning, but also a wide range of operations through imagined sensory perception, she identifies in the texts such fragments of the stories which relate to specific sensations caused in the real world using physical stimuli. The analysis constitutes only a case-based introductory study of the issue of senses in literary texts. She does not focus on the tale as an independent existential creation, which carries a multitude of interpretative references and meanings, only the possibilities offered by the analysis of a work, which consists of a transfer of a literary description to the imagination of the sensory experience occurring (hypothetically) in the receiver's imagination.

Keywords: fairy tales, ugliness, aesthetics, Grimm, aesthetic value, sensory vision. 